\title{
EXPLORING SOUL, NATURE, AND GOD. A TRIAD IN BHAGAVAD GITA
}

\author{
YADAV SUMATI* \\ G Govt. College for Girls
}

\begin{abstract}
Humans have always been and still are fascinated by the elusive phenomenon of soul and have devised various approaches to interpret it and attribute different names to it; depending on which part, which religion, which tribe and which sect of the world they belong to. Theologians to philosophers to spiritual thinkers to literary authors and critics to scientists-all seem to be researching and explaining its nature and place in the universal scheme of things. Interestingly, there is a unanimity among all, regarding the eternity and indestructibility of soul. The ancient Hindu scripture, Bhagavad Gita establishes soul (Jivatma) as a triad of Self, Nature (Prakriti: material reality) and God (Parmeshwara). The inner self is Soul which bears reflections of both, the physical nature and God. Malleable in ignorance, it identifies with the sense-perception dominated body but once realising its true nature, it is capable of governing the body and its actions. With the support mechanisms and persistence, it traverses across individual body consciousness to universal consciousness. This article strives to make a hermeneutic study of this metaphysical text; inquiring how awareness of the duality of nature; transient and permanent, triggers a gradual process of evolution, leading to a complete transformation when a soul resides within a body as a unifying factor; not for exploiting it or others or vice versa but for bringing about universal harmony.
\end{abstract}

KEY WORDS: soul, nature, God, spirituality, self-actualization

Therefore let the scripture be thy authority, in determining what ought to be done, or what ought not to be done. Knowing what hath been declared

by the ordinances of the scriptures, thou oughtest to work in this world

(Besant and Bhagavan 1905: 16.24)

\section{Introduction}

A very regular phenomenon perceived nowadays is that of the enquiry of the ancient religious, philosophical, and spiritual texts for any social, political, natural and personal issue; either to blame them as propagators of certain problematic tendencies, or to claim them as the practical wisdom

* Yadav Sumati (PhD) is Assistant Professor in the Department of English at PG Govt. College for Girls, Chandigarh, India. She explores mythology, theatre, and cinema studies.Email: sumati05@gmail.com. 
guides to be revisited, reconfigured and resituated in the changed circumstances of the fundamentally similar complexities of human existence. The former approach is feared to be conjoined by controversial judgmentalism whereas the latter is believed to be mining lessons and solutions, casting off the dark realities of fanaticism, bigotry and superstitions. The reach and scope of their influence on individual human psyche and the whole society is constantly established by the way their principles and teachings inform their conduct. It is not for nothing that academic disciplines like religious studies, practical / applied mythology, practical theology, applied philosophy, and applied spirituality have been so commonly running for higher studies. Moreover, researchers from all fields of knowledge, even pure and applied science too, have now been more so engaged in exploring the scriptural truth; either to validate them or to dismantle them. The most elusive of such truths is the concept of creation, soul and God; bewildering as well as comforting for human mind. These spiritual concepts, irrespective of the religion they are stated by, seem to be the only symbols of hope for the modern humanity mired in multifold conflicts and quandaries; because they still are seen to go beyond the reach of sciences and to furnish answers to the fundamental but crucial whys, whences, whats, whos, hows, of kaleidoscopic creation. And the fact to be marked here is that this recourse to spirituality is not as measured and conscious an effort as it is an inevitable and inherent a human tendency. And this is the only time tested refuge which humanity has to and need to be the asylee of, having tried and tasted the bitter-sweet fruits from the chimeric field of its egoistic potencies, and still remaining unsatiated.

The writing we set out to delve into in this article is Bhagavad Gita also known as The Song of the God. Although its familiarity with humanity goes as far as that of any prominent religious or philosophical texts, the ever recurring role it has as a transformative masterpiece seems unparalleled. The very criticality of the circumstances of its coming into being mark its significance as a gateway to relief, equability, and the so called elusive phenomenon of peace amid a warring scenario; inner or outer. This article serves as an exegesis of this metaphysical text and strives to explore how enmeshed with both critical outer and inner turbulence on a battlefield, how did the discourse on abstract topics like soul, eternity/non-eternity, yoga, renunciation could work on the Pandu warrior, Arjuna to convince him to take up arms and fight for righteousness. Besides, it seeks to find out if prone to all sorts of crises, as humanity now constantly is, the same wisdom of soul can work as a remedy for us, today's Arjunas. 


\section{The Analytical Interpretation of Bhagavad Gita}

The Hindu epic, Mahabharata by sage Vyasa records a large scale family feud involving many nations wherein the God-incarnate, Krishna sides with the rightful Pandavas. Bhagavad Gita situates itself as a lengthy discourse between the Pandu prince Arjuna and his charioteer, Lord Krishna on the battlefield of Kurukshetra, the greatest lived example of the victory of righteousness (dharma) over unrighteousness (adharma). The developments of the events in the narrative make the war seem inevitable; preparations have been done and emotions run high in both the camps. However, at the peak of this heightened scenario, the star warrior Arjuna, after surveying both the armies consisting of his kinsmen, suffers a nervous breakdown and like a conscientious objector, refuses to fight his own people and incur sin of fratricide. It is at this point that Lord Krishna makes him realise the paramount importance and justification of his duty of being a warrior (Kshatri$y a$ ), by gradually unmasking the associated dilemmas, doubts and complexities. And He does that by bringing home the idea of the imperishability, immutability, eternality of soul or being. His initial response to Arjuna's dejection regarding killing his own relatives is to mark the difference between the destructible material body and indestructible spark of the Divine, the embodied soul: 'He is not born, nor doth he die: nor having been ceaseth he any more to be; unborn, perpetual, eternal and ancient, he is not slain when the body is slaughtered' (Besant and Bhagavan 1905: 2.20).

There may seem nothing new in the idea of the soul being immortal, as majority of people believe it to be so through their respective religions or personal inklings. However, what is unique about the soul theory of Bhagavad Gita is its synthesizing proposition about cosmic reality. Krishna affirms the eternal reality of the cyclic creation and dissolution of the universe consisting of the sentient/non-sentient, living/non-living entities. Starting off with the Ancient Vedic scriptural descriptions regarding the dual nature of existences comprising of the material and the spiritual nature, this text takes this concept on a level which is both abstract as well as concrete. When Krishna talks of Nature (Prakriti), he is not just talking about the material reality of and around us, he is talking of the whole scheme of the cosmic reality wherein the Supreme Lord (Parmeshawara / Purushottama) manifests Himself in the creation in a twofold way: through His lower, material, transient, physically manifest nature (Kshra / Apara Prakriti) consisting of the five basic elements of earth, water fire, air, ether (corresponding to the five outer senses), mind, reason/intellect, and ego; and his higher nature (Akshra / Para Prakriti), the consciousness, being, soul (Atma / Jiva / Purusha), the life giving energy or 'the life element' (Besant and Bhagavan 1905: 17.6).

The further reality of existence reveals that the highest immutable Self, the Supreme Lord, invested with the plenary powers effects the constant 
creation, preservation and dissolution of the universe. And that too happens on two levels: One, He pervades the entire phenomenal creation and governs it; two, He lends a spark, a touch, an infinitesimal part of his divinity (individual soul, Jiva / Atma) to all the beings which then, get embodied and act according to the dominating tendencies among Purity, Passion and Darkness (Sattwa, Rajas, and Tamas; Triguna in Apara Prakriti) of the physical bodies. It is with the union of the material and spiritual essence that starts a life in which, interestingly and surprisingly both, the presence of the soul effects the process but it still remains immutable; it is only the lower nature that acts: "All actions are wrought by the qualities of nature only. The self, deluded by egoism, thinketh: "I am the doer"' (Besant and Bhagavan 1905: 3.27). Moreover, it is not like a one-act play which will come to an end with the end of a body; the soul goes on and on transmigrating from one body to another until it, either supported by Intellect, the discriminatory power or by some outer agency like a scripture or a spiritual teacher, recognises its truth and starts detaching from the desires which bind it with the chain of action-reaction (karma).

However, what pulls the rug from under the feet and completely unsettles a reader is the revelation regarding the single but powerful letter 'I'. The 'I' and the words 'my', 'mine', 'me' which we invariably associate with our physical bodies and personalities are at once, with a jerk, redefined and diverted to our consciousness i.e. our soul which has a veil of illusion drawn before it by the senses, mind and ego, making it superimpose the physical reality upon itself, which is not its quintessence. And instead of meeting the Opulent One of its kind, it is led away by the force of the differently combined three elements (Triguna) of material nature, worse so if the dominant elements of a body is the Dark (Tamas) one. And thus subjecting itself to a complete identification with the body, it starts owning everything the body goes through: the experience of the pairs of opposites such as good and bad, pleasure and pain, joy and sorrow, success and failure etc. How this happens is explained by Krishna thus 'man, musing on the objects of sense, conceiveth an attachment to these; from attachment ariseth desire; from desire anger cometh forth; from anger proceedeth delusion; from delusion confused memory; from confused memory the destruction of Reason; from destruction of Reason he perishes' (Besant and Bhagavan 1905: 62-63).

'Perishing' here implies the inability to scale the spiritual heights of selfrealisation and attain the real supreme bliss which can only be attained by acquiring the stage of inner renunciation of attachment to sense-objects and the desire for the fruit of action and resignation of thus purified individual consciousness to the cosmic consciousness, the Supreme Divine Self. Krishna, as the Supreme Lord of beings in his essential unmanifested form, explains this communion of the two spiritual principles of the triad of living 
creation i.e. individual soul (Jivatma) material nature (Prakriti) and Supersoul/God (Parmeshvara):

Abandoning without reserve all desires born of the imagination, by the mind curbing in the aggregate of all the senses from every side, little by little let him gain tranquillity by means of reason controlled by steadiness, having made the mind abide in the self, let him not think of anything... Supreme joy is for this yogi whose mind is peaceful, whose passion-nature is calmed, who is sinless and of the nature of the Eternal (Besant and Bhagavan 1905: 6.24-25, 27).

Here Yogi is the one who has actualized the self, and who, with practice rises up the ladder of spiritual heights, leaving behind all the traces of bondage and performing his duties as sacrifice (Yagya), an offering to God: 'Whatsoever thou doest, whatsoever thou eatest, whatsoever thou offerest, whatsoever thou givest, whatsoever thou doest of austerity, O Kaunteya, do thou that as an offering unto Me. Thus shalt thou be liberated from the bonds of action, yielding good and evil fruit; thyself harmonised by the yoga of renunciation, thou shalt come unto Me when set free' (Besant and Bhagavan 1905: 9.27-28). The only wisdom Bhagavad Gita deems fit for any seeker is knowing the true nature of matter and soul, the body as a field (of activity), and God as Omnipresent, Omniscient and Omnipotent. And this practice involves evolving the pure (Sattvik) element of one's nature through preventing the passion-oriented and dark qualities from influencing the mind. And this further, according to Krishna, necessitates purity of knowledge (of the all-pervading yet distinct Absolute Self), purity of action (ordained according to the dominant material element), purity of actor / doer (steadfast, mentally equable, and cut off from causes of bondage) and purity of Reason (sound judgement): 'The relinquisher pervaded by purity, intelligent and with doubts cut away, hateth not unpleasurable action nor is attached to pleasurable. Nor indeed can embodied beings completely relinquish action; verily he who relinquished the fruit of action he is said to be a relinquisher. Evil and mixed threefold is the fruit of action hereafter for the non-relinquisher; but there is none ever for the renouncer' (Besant and Bhagavan 1905: 18.10-12).

Such recommended relinquishment (Tyaga) as a pre-condition to mental renunciation can be attained through any method of the following three practices and contemplation: Devotion (Bhakti Yoga), Wisdom (Gyan Yoga) and Action/Duty (Karma Yoga). When we actually come to reflect upon it in the context of today's technology ruled world, reading Gita is like traversing through a digital narrative on a computer monitor which allows us the free choice of routes or path through various nodes. We take the route of our choice and meet the result that is corresponding to our choice. Notably, Krishna recommends Karma Yoga which lets the intellectually steadfast 
(Sthitpragya) purify their beings at their own pace, adjusting the distribution of qualities (Guna), tilting the balance in favour of sattva, while performing their ordained duties. They, while being in a gamut of spiritual variables; different, gradually evolving stages, advance from attachment to relinquishment to inner renunciation to ultimate divine bliss and still be outwardly active for the welfare and harmony of society: 'They who worship the Indestructible, the Ineffable, the Unmanifested, Omnipresent, Unchanging, Immutable, Eternal, restraining and subduing the senses, regarding everything equally, in the welfare of all rejoicing, these also come unto Me' (Besant and Bhagavan 1905: 12.3-4).

This becomes the underlying principle of all that Krishna elaborates on an ordinary person's spiritual journey and destination. And the sole purpose of the whole discourse is to reiterate and uphold this principle. During the Bhakti (devotion) movement of the mediaeval India, various saints and devotees like Surdas, Raskhan, Raidas, Rahim, Bihari, Mirabai, Karmabai et all, surprisingly irrespective of their region, religion, caste and gender, articulated and lived in what some devotees now call Pure/ Krishna Consciousness. Various translations and analytical commentaries have been written on it in India; right from the sages of Indian order of monks like Shankaracharya, Sridhara Swami, Madhvacharya, Vivekananda, Sri Aurobindo, to various social and political leaders like Mahatma Gandhi and Vinoba Bhave. Various sects of Krishna devotees like ISKON, Hare Krishna are spread all over the world, preaching and practicing his teachings. Besides the above listed Indian thinkers, German physicist Albert Einstein, American author and philosopher Henry David Thoreau, French-German theologian Albert Schweitzer, Swiss psychiatrist Carl Jung, German-Swiss author Herman Hesse, American author Ralph Waldo Emerson, Austrian philosopher Rudolph Steiner, English author and philosopher Aldous Huxley, and Norwegian philosopher Arne Naess have acknowledged the influence of Bhagavad Gita as didactic guide to spiritual evolution.

Although this all-inclusive concept of soul, told in the now almost defunct script Sanskrit, risks misinterpretation and unanimity may not exist in their perceptions about its propositions, this apparent lacuna also provides flexibility as towards expansion of meaning natural for any scripture. What Joseph Campbell says about mythology holds true for this sacred scripture, Bhagavad Gita, too; that it is 'a poetic, supernormal image, conceived... in depth, but susceptible of interpretation on various levels. The shallowest minds see in it the local scenery; the deepest, the foreground of the void; and between are the stages of the Way from the ethnic to the elementary idea, the local to the universal being, which is Every man, as he both knows and is afraid to know' (Campbell 1987: 472). 


\section{Literature Review and Methodology}

It is beyond the limited scope of an article to cover all the research studies on Bhagavad Gita so a restrained list of a few representational studies has been taken into account.

In addition to the various disseminative approaches to Bhagavad Gita directed towards man's initiation into self-realization, there have been other scattered and selective methodologies confirming the perennial relevance of its deliberations in various fields of human activities; mental, emotional, physical, within or without. Sri Swami Sivanand asserts that 'a busy man with an active temperament will be greatly benefited by the commentary of Sri Gangadhar Lokamanya Tilak, entitled Gita Rahasya. A man of devotional temperament will be attracted by Sri Sridhara's commentary, and a man of reason by that of Sri Shankara' (Bhagavad Gita). A.V. Srinivasan in his book, The Bhagavad Gita: A Thread through the Eighteen Gems pronounces: 'So, the message of Gita is detached dynamism, egoless activity, efficiency, and courage and self-realization [...] This unique Hindu gospel... does not require anyone abandoning their jobs or fleeing from families, tampering their plans, disturbing their own faiths [...] The object of Srimat Bhagavad Gita is to remove our ignorance' (Epilogue). Vamsi Palem stresses the doctrine of charity (alms giving in Bhagavad Gita) as a means to eternal peace for the soul, in her comparative study Bible, Bhagavad-Gita, and Billionaires. Franklin Edgerton calls it 'the Bible of India' in his own translation (Edgerton 1994: $\mathrm{x})$. Venkobrao declares Gita to be 'the masterpiece of psychotherapy', picking up the role mind has been assigned in bewildering the soul and block its understanding of itself (Venkobrao 2002: 32). On one hand, Michael C. Dilbeck traces Mahrishi Mahesh Yogi's theory of Vedic Psychology in Bhagavad Gita in terms of its emphasis on 'full integration of life' by establishing the individual consciousness in the field of core consciousness which the Maharishi calls 'the unified field of natural law' (for more interesting details about this topic, see Dilbeck 2016; also, Larson 1981: 513-541). On the other hand, John S. Hagelin contemplates on the Maharishi's hints at identicality the unified field of modern theoretical physics and the field of pure consciousness' (Hagelin 1987: 29). Moreover, this basic model of the initiation into self-realization leading to attunement with the Supreme Consciousness pervading everything becomes the basis of an ecological survey of Bhagavad Gita's for some. Arne Naes, who gave us the concept of ecosophy, owes his inspiration from Gita to Mahatma Gandhi.

Bhagavad Gita 6.29 sums up, according to Naess, the maximum of selfrealization. It expresses the idea that all is connected to everything else and therefore that the self-realization of any living being is part of the self realization of each one of us' (Taylor 2006: 1149). Interestingly, Bhattathiri asserts that Krishna's motivational discourse on the process of managing the 
life consisting of matter and soul: 'The Bhagavad Gita... enlightens us on all managerial techniques leading us towards a harmonious and blissful state of affairs in place of the conflict, tensions, poor productivity, absence of motivation. He also explores 'alternate paradigms for better management practices' in his theory of dispassionate action, sacrifice, duality of cosmic spiritual element and equanimity (see Bhattathiri quoted in Acharya 2015: 7376). Emphasizing the import of Bhagavad Gita in imparting the crucial aspect of spiritual well-being to the concept of health in Indian psychiatry system, Ravi Shankar Rao reckons that in addition to the formation of the physical, emotional and intellectual personality is the uniqueness of the Atman in creating the spiritual personality. The cognitive restructuring done by Krishna on Arjuna by taking Him through the Yoga of Jnana, Bhakti, and Karma provides a holistic framework conducive to freedom from psychological conflicts' (see Rao 2009: 233-234). However, such fragmentary approaches to Bhagavad Gita may not do justice to such a vast matrix of spiritual ideology, as they do not strive to take in the discourse as a whole and overwhelmed by a present or perceived crisis of a personal or collective life, seek instant remedies. Although seemingly unrelated, it can be clearly understood by an analogy that even a layman can comprehend. It is a comparison of these selective approaches as allopathic ways of curing, and a holistic approach as the homeopathic method of healing. Whereas the former seeks the preventive techniques for symptomatic treatment, the latter goes by etiological diagnosis for the holistic treatment of a malady by taking into account all the innate constitutional complications. Certainly, even with the caveats of the secondary effects, if one is most suitable for immediate respite for physical trauma, the other's therapies suit best for the physical or psychological illnesses born out hormonal imbalances.

Ananda K. Pandurangi nails it when he stresses that the Gita, besides being a Hindu philosophical scripture, is also 'a work of theology, spirituality, human psychology, and ethics' (Pandurangi, Shenoy, and Keshavan 2014: 827-828). Bhagavad Gita is supposed to work like a time-tested therapy for the salvage the desire-afflicted soul by building up the complete immune system. Initially, an aspirer may wish to withdraw for fear of its being a long, challenging process, of making wrong choices and of not meeting success, but the last chapter, the 18th, sums it all; it takes total obedience, reliance and surrender of self to the Self for eternal peace and bliss: Merge thy mind in Me, be My devotee, sacrifice to Me, prostrate thyself before Me, thou shalt come even to Me. I pledge thee My troth; thou art dear to Me' (Besant and Bhagavan 1905: 18.65). The statement of purpose of this narrative is openly and succinctly informed by Krishna in the form of a question; whether Arjuna had heard it with one-pointed mind, and whether his delusion, caused by his unwisdom has been destroyed. And with Arjuna's 
response in affirmation, this dialogue on highest for wisdom (Brahmvidya) comes to an end. Therefore, as a whole, it perfectly exemplifies a session of deep psychotherapy which, instead of admonishing, emotionally blackmailing or inflating his ego, makes Arjuna introspect and know himself as a soul not in subjugation but dominance over the body. And this surely helps him to heal essentially by broadening his worldview, the purpose of his life and the pleasure lying therein albeit hard earned: 'Which at first is as venom but in the end is as nectar; that pleasure is said to be pure, born of the blissful knowledge of the SELF (Besant and Bhagavan 1905: 18.37).

Initially, it is inevitable for an aspirant to be bewildered at the range of a complex field of cosmic experience with the intricacies of different energies at work. Sorting the various levels of the creation in abstract terms may not be inspiring for many. A number of exegeses put an ordinary being in the predicament of judgement. Although mystifying, grasping the enigma of soul, God and universal existential oneness is akin to walking a tightrope and the fascination does not last long for most of us. In fact, Krishna, an allinformed Yogi, apprehends this and predicts the impracticality of expecting one and all to actually cross the threshold, step into the maddening whirlwind of conflicting tendencies and alternative dynamisms and work their way through it; identifying the suitable mechanism, synergising with the uplifting forces and either getting stuck midway or ending up being established in the whole. He acknowledges the complexity of understanding this mysterious, elusive and subtle phenomenon of self: 'As marvellous one regardeth him (the soul); as marvellous another speaketh thereof; as marvellous another heareth thereof; yet having heard, none indeed understandeth' (Besant and Bhagavan 1905: 2.29); 'Among thousands of men scarce one striveth for perfection; of the successful strivers scarce one knoweth Me in essence' (Besant and Bhagavan 1905: 7.3). He chose only Arjuna to enlighten with this decisive wisdom, and he calls Arjuna the best of his lineage and the sinless one who qualifies for it. The skeletal framework of Bhagavad Gita, the treasure house of universal wisdom, is succinctly stated in the fifth chapter:

He who is harmonised by yoga, the self-purified, self-ruled, the senses subdued, whose SELF is the SELF of all beings, although acting he is not affected. 'I do not anything', should think the harmonised one, who knoweth the Essence of things; seeing, hearing, touching, smelling, eating, moving, sleeping, breathing, speaking, giving, grasping, opening and closing the eyes, he holdeth: 'The senses move among the objects of the senses' [...] Yogis, having abandoned attachment, perform action and even by the senses, for the purification of the self [...] The harmonised man, having abandoned the fruit of action, attaineth to the eternal Peace; the non-harmonised, impelled by desire, attached to fruit, are bound. Mentally renouncing all actions, the sovereign dweller in the body resteth serenely in the nine-gated city (body), neither acting nor causing to act (12-13) [...] 
Verily, in whom unwisdom is destroyed by the wisdom of the SELF, in them wisdom, shining as the sun, reveals the Supreme. Thinking on THAT, merged in THAT, established in THAT, solely devoted to THAT, they go whence there is no return, their sins dispelled by wisdom (Besant and Bhagavan 1905: 5.7$9,11,12-13,16-17)$.

On the surface, it appeals like any scriptural template for an ideal life which an ordinary person engaged in the quandary of worldly affairs routinely hears dutifully, follows ritually and feels devotional to as well. But it is rarely that he thinks he can afford to contemplate about following it steadfastly. Krishna, having surveyed human life through ages, as the Supreme Lord as well as His personalised, incarnated (Avtar) form, knows about this attitude of humans and dispels it too by suggesting the fourfold paths to free their soul from the sensory and mental bondage and help salvage other soul too (for a description of these paths, see Easwaran 2004: 153, 116, 160, etc.). We have the ingredients and He, the recipes. We can choose the one that is best suited to our taste and temperament and work upon it. Followed faithfully and substantively, the combination of the prescribed ingredients will result as tasty as the recipe giver assures. Of course, the resultant taste might vary if we put much or less, carefully or casually, disinterestedly, passionately, or passively, and do not cook it thoroughly. 'Krishna proclaims the corresponding relation between the degree of spiritual growth in a man and the nature and extent of his efforts. The worship of the Gods is not quite useless. The worshippers do attain results suited to the form of worship, but they have to return to this world after a time' (Besant and Bhagavan 1905: 9.24). The analysis of the formulations of Bhagavad Gita reveals their deep link with a mechanism of action to foster well-being, and their positive effects on an individual as well as a community.

\section{Science of the Soul and Existential Crises. The Personal Level}

After identifying ourselves as pure souls, what we are supposed to do is like the spiritual house cleansing; driving away negative energies which are incompatible or unconducive to our evolution, and firmly, constantly developing the conducive ones. It is the extent and gravity of the required selfregulation which makes Arjuna also wonder if one lifetime is enough to reach to that state of steadfast, unattached performer self-actualized. He asks Krishna what if the body dies without the fruits of our past actions being exhausted. Does a soul has to start all over again when it takes up a new body?

Krishna gives some basic premises regarding this: no one can escape action. Whichever be the dominant tendency, action done with attachment to its fruit adds to karma. Righteous action like devotion, sacrifice and gifts, performed attachedly, with a firm mind does yield fruit according to the 
intent. Righteous action, performed unattachedly with a firm mind does not yield fruit. The balance of the previously accumulated fruits gets carried over in the next state of manifestation, i. e. life. The next embodiment of the soul is according to the dominant tendency of the action-fruits it carries with itself. Tendencies are flexible and their aggregate can be reconfigured too. In times like today's, when we witness the majority of us being rajas and tamas oriented, going about life multitasking to be the fittest survivors, the prime purpose of life, spiritual health has been reduced to be a recreational activity in requirement of an appointment based session to attend to. Despite all the boasts of achievements and marks of greatness, we hanker for something to make it a full circle. But fulfillment evades because we miss the most crucial venture to invest and exhaust our resources and energies in. This, at last, compels some to take recourse in spirituality. In fact, the need for a self-initiated purgatory process for spiritual healing is witnessed at present than any other time in human history. Had it not been so, variety of self-proclaimed saints and gurus, scripturally qualified or not, would not have generated hysterical mass following.

Nevertheless, the verisimilitudes of multiple paths and meaning derived from Bhagavad Gita revolve around only one phenomena; the theorem of the liberation of soul, its realisation of the Absolute and harmony within and without. Once a seeker stars off with the true knowledge of the inherent duality of his own personality and the concurrent dual reality of the $\mathrm{Su}$ preme, unmanifested cosmic being, permeating through all the organic or inorganic entities, governing the manifested nature through its three stages of cyclical progression; beginning, middle, and end. As it is, we all dream about ultimate satisfaction in our lives and Krishna provides us the formula. We are constantly concerned about future now and hereafter and he shows us the way. But it is all conditional: we have to know the nature of that satisfaction and have to act for it. This masterpiece of mysticism, Krishna's Bhagavad Gita shows that the sanctity of the soul has to be preserved, and residing in the body it is not capable of doing it alone, so it develops the penchant for complete surrender to the Supreme God, the highest universal authority, the source of all and everything.

When one says blood is thicker than water, one states the natural order of priority for a person in terms of bonding with and obligations towards the people related to us, and our blood relations, especially the core family becomes primary. On a higher spiritual plane, the essential lineage is traced to the Absolute Divine, God. Everything else, the transient material nature in the form of the basic eight elements in their numerous forms as bodies and its subtle qualities in their various combinations, becomes secondary. We just have to 'wake up' to the reality of our soul, and train it to retain its essential purity. The qualities of the pure embodied souls, the passionate 
souls and the dark souls, as listed in Bhagavad Gita, serve as yardsticks to measure our own qualities by and to identify our personality type. While attributing all pure virtues and qualities to the persons of 'divine properties' Krishna, the supreme visionary warns Arjuna against the demoniacal men (Asura) who are dominated by the dark tendencies of lust, wrath and greed which he calls 'destructive of the self' and 'triple gates of hell' (Besant and Bhagavan 1905: 16.3, 21).

At the personal level, Bhagavad Gita works as an eternal practical wisdom guide. It presents a prototypical process assuring in a well physiological, mental, emotional and spiritual integrity and harmonized energies. There is no fixed threshold as to where and when to do for it, except for how to facilitate the self to reclaim itself and start internalising the comprehensive worldview of Bhagavad Gita effectively. It is in fact a school in itself which teaches humanity the science of soul in its entirety. And even if written in spiritual manner, the delineation of the reality of our soul, mired in illusion and mind, a force to reckon with when complacent to senses, is logical. Conceptually, mind is analogous to the biological phenomenon called neuron, the basic nerve cell to process and transmit information between the central nervous system; the brain and spinal cord. The role of mind in keeping the soul from redemption by signalling it the wrong way, can be explained by drawing parallel between the two. In Bhagavad Gita's concept of the reality of an individual's soul within and integral to the sphere of the cosmic reality, Mind functions in a human constitution like a neuron, the semi-permeable cell membrane as reason/intellect, ions as natural quality (guna) based desires, central nervous system as soul and the stimulus as multiple desires. Like a cell membrane, the intellect can also block some of the negative desires from the mind but not all. Mind when not activated by desires has the resting potential. However, due to the constant force of desire based actions, the mind undergoes a change in terms of the shift in the proportional ratio of the qualities similar to depolarisation. And when, the ratio of the desires inside the mind reduces in proportion to the other differently combined desires outside it, the mind cannot withhold their entry and reaches the threshold potential. And then, it fires an action potential to the soul which based on the dominant quality of the powerful desires. Eventually, the ignorant soul obeys and incurs the consequential bondage.

Krishna as a perfect teacher, yogi and all time guide, hands out the worksheets for the personality development and capacity building programs, to fulfill the requirement of freedom from the bondages. The exercise that we, the embodied ones need to take up is to replace the stimulus of rajas and tamas laced desires with sattva based ones. Then the mind will it self be pure and inform the soul accordingly. Krishna necessitated 'purity of food, sacrifice, austerity, and alms-giving' (Besant and Bhagavan 1905: 
17.7). Purity of austerity has further been divided into three categories: of body, speech, and mind. If earned and sustained firmly, according to this masterpiece of mysticism, Bhagavad Gita, this dynamic wisdom and its practice, coupled with a thorough devotion to the God or whatever terminology we use to assign to the unseen but eternal ruler and regulator of the cosmos, are the 'spiritual safety valves... in a spiritually suffocating world' (Barger 2007: 88). Fulfilling the spiritual quest of being permanently, comfortably established in the self has the potential to make us experience ourselves as integrated whole and streamline our lives around the principle of unity in diversity at every level of this vast spectrum of creation.

In this regard, even if Krishna is regarded without any divinity attached to him, he works wonders psychologically. His lessons make us crisis resilient: 'Gita... supports the role of duty and participation-joyful participation in the sorrows of the world' (Campbell 1987: 472). In fact, it works on many levels of human experiences. It convinces us, like it did Arjuna, to set new paradigms in our life in terms of our identity, our duties, our goal and our relationship with the Supreme Divine. It makes us flexible to accept change as crucial to subsistence and evolution. It makes us accommodate death as one of the natural stages of body's life cycle on earth. It makes us compatible with our surroundings at both micro and macro level. Fulfilling the spiritual quest of being permanently, comfortably established in the self has the potential to make us experience ourselves as integrated whole and streamline our lives around the principle of unity in diversity at every level of this vast spectrum of creation.

\section{Science of the Soul and Existential Crises. The Community Level}

The existential crises which all sorts of sensate and insensate resources are going through at present, poses the threat of a big disastrous future. Bhagavad Gita lets us learn to address our vulnerabilities and the nuances of managing all sorts of consequential emergencies with a proactive, action oriented approach which covers all sorts of tactics to minimise the risk of loss to the overall health of an individual, society and environment. It persuades us to make spiritual growth a vital aspect of our future oriented decision making at every stage of our life. If we let our soul remain with the role it mistakenly takes up, the risk gets manifold. Bhagavad Gita puts the onus on us to understand the perils of the transient, Guna oriented existence. It gifts us such a coping mechanism, Venkobrao says, that it can be implemented as needed on a flexible and scalable manner in all phases of disaster management: (1) mitigation (prevention and risk reduction), (2) preparedness, (3) response, and (4) recovery (immediate restoration to build-back better)' (Venkobrao 2016). 
Further, Bhagavad Gita's insightful multi-leveled directives for addressing any crisis enlightens us on the ever-increasing ecological crisis looming all over the world in some or other form. Mostly anthropogenic, such threatening shifts in the ecological equation between man and nature can be clearly understood if we measure our real attitudes towards universal natural resources and the worldview projected and preferred by Krishna. His universe is a harmonized whole, a symphony of rhythms of life created and presented by God, and beautifully coloured canvas of ecosystems. Every visible or invisible phenomenon partakes and participates in the ecological harmony propounded by Krishna: That by which one indestructible Being is seen in all beings, inseparate in the separated, know thou that knowledge as pure (Besant and Bhagavan 1905: 10.20). A self-actualized being acknowledges this and identifies his part and place in this universal oneness; recognising one divine thread passing through one and all, including himself. This ecological wisdom is thoroughly reflected in Arne Naess's ecosophy (ecological philosophy). He emphasises the same interrelationship of humans and their natural environment when he talks about 'ecological harmony or equilibrium' (Naess quoted in Grange 2015: 301308; also Naess 1989: 194 forward). A philosophy as a kind of sofia (or) wisdom, is openly normative, it contains both norms, rules, postulates, value priority announcements and hypotheses concerning the state of affairs in our universe. Wisdom is policy wisdom, prescription, not only scientific description and prediction. The details of an ecosophy will show many variations due to significant differences concerning not only the 'facts' of pollution, resources, population, etc. but also value priorities' (Grange 2015: 301 308). The value system in the ecosophy of Bhagavad Gita underlines the acknowledgement of the symbiotic relationship with the environment whereby exploitation or domination of one over the other is to be renounced. Significantly, this deep ecology of Bhagavad Gita is unmistakably realized by the self-realized pure soul: 'The self, harmonised by yoga, seeth the SELF abiding in all beings, all beings in the SELF; everywhere he seeth the same' (Besant and Bhagavan 1905: 6.29).

For the comprehensive evolution of persons, societies and ecosystems, the wisdom of soul and its realization become the conditional premise of the formula of environmental conservation. It is the Core value which entails many instrumental values; a full range of value priorities, accommodative of different temperaments, which through the constitutional coordination at both personal and social level, can contribute in rendering the wide-ranging mechanism of conservation effective. Moreover, the degree of personal or social well-being and progress will be proportional to the degree of environmental sustenance. It is said that our realisation of self occasions with the simultaneous realisation of the un-manifested, all pervading Supreme 
(Yogananda 2005: II.585, 598). The Absolute Self is an underlying principle of everything, the innermost essence. Knowing one and not knowing the other is not possible because $\mathrm{He}$ is the sustainer of the whole cosmos; 'the splendour of the sun, moon and fire', 'the vital energy of soil and sap of plants', and 'the Fire of life' in breathing things' (Besant and Bhagavan 1905: 15.12-14). However, the dark qualities make man ignore this powerful fact in their ego. By virtue of their latent reason, they exploit whatever they can to fulfil their desires. Everyone is, directly or indirectly involved in this affront to the God itself. Self-recognised, we souls can also recognize the reality that the Supreme Self supports whole universe including all differentiated organisms and things. And such wisdom and purity promote love and peace, not hatred and violence.

Bhagavad Gita marks a paradigm shift in the history of Indian spiritual consciousness. Although rooted in the tenets of broader Hinduism, it has expanded the scope and meaning of the basic concepts like soul, the God, nature, and their relation with each other. Casting off the extra baggage of rituals, rigidity and fixedness, these fundamental yet ever-evolving truths have been re-configured through an integrated perception. Readers like Bakhtin believed that the lessons in Bhagavad Gita ensure personal spiritual growth (cf. Davis 2015: 205) as well as social harmony through the common goal of liberation for all, through alternative paths, realizing love for both his transcendent and immanent form and thereby whole humanity: 'Restraining and subduing the senses, regarding everything equally, in the welfare of all rejoicing, these also come unto Me' (Besant and Bhagavan 1905: 12.4). Spiritual wisdom and evolution do not strictly impose with sectorial limitations. They have been so harmonized with human nature that spiritual aspirations are not the prerogative of any particular class. Anybody, having acquired the mandatory qualifications through devotion, knowledge, action can scale the heights of the ideal state according to their capacities. The image of a world it projects albeit guardedly serves as a pattern for the most evolved civilization till date (Davis 2015: 116). Krishna, subverting the Vedic belief of social division, declared it to be operational based not on birth (Janma) but fruits of action (karma). He linked to the idea of soul; a soul gets embodied in a particular class based on 'the different distribution of qualities and actions (guna and karma)' (Besant and Bhagavan 1905: 4.13), as determined by his previous births and actions. However, a person has the free choice in manipulating the flexibility in that distribution and can strive to endow himself differently. Besides, even social harmony and coordination is proposed to be ensured by each person sticking to the duty prescribed in line with his tendencies and not interfering with the other's field of action. 


\section{Conclusions}

Conceptually all said, there has been a long order of sages, mystics and devotees of Krishna who have lived His codes of conduct in the Bhagavad Gita by example and have established themselves as perfect ascetics (yogi) of wisdom, devotion and action, irrespective of their caste, class and community. Most of them belong to the medieval India when all these criteria were clearly demarcated and were not compromised with. The hymns composed by them still inspire people and their recital at some or other place is a regular in this part of the world. A few examples will serve the purpose of showcasing their ultimate identification with Krishna's words in Bhagavad Gita. Kabir Das accedes to the idea of wisdom of soul and the enlightenment it brings: Jab Mein Tha Tab Hari Nahin, Ab Hari Hai Mein Nahin, Sab Andhiyara Mit Gaya, Jab Deepak Dekhya Mahin (When I [ego] was there, God was absent, when the inner flame / light shined forth, all the darkness disappeared). Rahim exemplifies pure sacrifice of alms giving in the following way; Denhar koi aur hai, bhejat jo din raen, log bharam hum par karein, taso neeche naen (The Giver is someone else, giving day and night. But the world gives me the credit, so I lower my eyes). Ravidas, a devotee of the Supreme in manifested and un-manifested form validates what skeptics question-mark: 'Hari [God] in everything, everything in Hari-He who knows Hari and the self, does not need any other testimony' the knower is absorbed. Sikhism owes many of its concepts to Bhagavad Gita.

At present, there are some spiritual leaders, at least in as much as they can disseminate the scriptural principles effectively, who have written their own commentaries on Bhagavad Gita in order to enlighten with their sermons and different yoga practices. The prominent ones are: Sadguru Jaggi vasudev of Isha Foundation, Sri Sri Ravishankar of Art of Living, Mata Amritanandmayi and Brahmkumaris, Osho foundation, and Maharishi Mahesh Yogi. Maharishi Yogi's proposal regarding 'the influence of coherence and positivity in the social and natural environment generated by the practice of the Transcendental Meditation and Sidhi programs popularly known as the 'Maharishi effect' (www.mum.edu/about-mum). All in all, Krishna's teaching finds resonance either within the souls or scriptures around the world, as most of the scriptural teaching do, because the obligation of sustaining life and conserving environs comes to the reasonable creatures. Manage this mountainous task is possible only through realising the soul's true potential. Followers of Krishna's spiritual framework say it cuts across boundaries of cultures, countries and continents, and if they can provide answers and remedy to the concerns of the world it is beyond geographical and ideological boundaries. It is felt that the wisdom of their scriptures is the reason most of the major civilizations have survived thousands of years, while in the present time, which is terribly conflict-ridden at multiple levels, the 
healing power of spirituality is all the more significant. Many hope that the applicability, adaptability, and relevance of Bhagavad Gita's spiritual doctrines contribute in transforming souls into equanimous beings and the frequency of Maharishi Mahesh Yogi's 'Maharishi effect' increases.

\section{Bibliography}

Acharya SK (2015) Lessons in Management from 'Bhagavad Gita'. International Journal of Research and Development-A Management Review 4(2): 7376.

Barger LC (2007) Chasing Sophia: Reclaiming the Lost Wisdom of Jesus. San Francisco, CA: Jossey-Bass.

Besant A and Bhagavan D (1905) Bhagavad Gita. London: Theosophical Publishing Society.

Campbell J (1987) The Mask of God, volume 1. New York, NY: Penguin.

Davis RH (2015) The Bhagavad Gita. A Biography. Princeton, NJ: Princeton University Press.

Dilbeck MC (2016) The Bhagavad-Gita: A Case Study in Vedic Psychology. https://www.mum.edu/pdf_msvs/v04/dillbeck.pdf, 30 October 2016.

Easwaran E (2004) Bhagavad Gita [with chapter introductions by Diana Morrison]. Boston and London: Shambhala.

Edgerton F (1994) The Bhagavad Gita. New Delhi: Motilal Banarasidas.

Larson GJ (1981) The Song Celestial: Two Centuries of the 'Bhagavad Gita' in English. Philosophy East and West 31(4): 513-541.

Le Grange L (2015) Ubuntu / botho as ecosophy and ecophilosophy. Journal of Human Ecology 49(3): 301-308.

Hagelin JS (1987) Is Consciousness the Unified Field? A Field Theorist's Perspective. Modern Science and Vedic Science 1(*): 29-87.

Naess A (1989) Ecology, Community and Lifestyle. Outline of an Ecosophy [translated and revised by David Rothenberg]. Cambridge: Cambridge University Press.

Palem V (2014) Bible, Bhagavad-Gita and Billionaires. New Delhi: A Penguin Random House Company.

Pandurangi A, Shenoy S, Keshavan MS (2014) Psychotherapy in the Bhagavad Gita, the Hindu Scriptural Text. Images in Psychiatry 171(8): 827-828.

Rao BRRS (2009) Spirituality and Mental Health: Reflections of the Past, Applications in Present, Projections for Future. Indian Journal of Psychiatry 51(3): 233-234.

Sivanand SS (2016) Bhagavad Gita. Uttar Pradesh: Divine Life Society Publication.

Srinivasan AV (2016) The Bhagavad Gita: A Thread through the Eighteen Gems. Glastonbury, CT: Periplus Line. 
Taylor B (2006) Encyclopedia of Religion and Nature. New York, NY: Continuum.

Venkobrao A (2002) 'Mind' in Indian Philosophy. Indian Journal of Psychiatry 44(4): 32.

Venkobrao A (2016) Maharishi Effect. The National Disaster Management Authority, Government of India, National Disaster Management Plan, New Delhi.

Yogananda P (2005) God Talks with Arjuna. The Bhagavad Gita. Los Angeles, CA: Self-Realization Fellowship. 